\title{
Response of the Cerebral Circulation to Hypocarbia in Postasphyxia Newborn Lambs
}

\author{
ADAM A. ROSENBERG \\ Department of Pediatrics, Section of Neonatology, The Children's Hospital and School of Medicine of University \\ of Colorado Health Sciences Center, Denver, Colorado 80218.
}

\begin{abstract}
Respiratory alkalosis is used in the treatment of newborn infants with persistent pulmonary hypertension. Many of these infants have suffered a prior asphyxial insult. Previous studies in a newborn lamb postasphyxia model have demonstrated abnormalities in the response of the cerebral circulation to hypoxia and to changes in blood pressure. Although vasodilation in response to these stimuli was impaired, the ability of the brain to extract oxygen was not. Therefore, because the principal response of the cerebral circulation to lowering arterial carbon dioxide tension is vasoconstriction with a compensatory increase in oxygen extraction, it was hypothesized that the postasphyxia response of the cerebral circulation to decreases in carbon dioxide tension would be intact. Ten newborn lambs were subjected to an asphyxial insult. Postasphyxia whole brain and regional blood flows were measured at three to four different levels of arterial carbon dioxide tension using the radiolabeled microsphere technique. In addition, arterial and venous oxygen content and blood gases were measured in the brachiocephalic artery and the sagittal sinus. The response of whole brain cerebral blood flow (CBF) to changes in arterial carbon dioxide tension $\left(\mathrm{PaCO}_{2}\right)$ is described by $\ln \mathrm{CBF}=\mathbf{0 . 0 3 1}$ $\mathrm{PaCO}_{2}+3.15(r=0.83, p<0.001)$. Responses of individual brain regions did not differ from whole brain flow. Cerebral oxygen consumption remained stable, and fractional $\mathrm{O}_{2}$ extraction (E) increased according to the relationship $\ln (1$ $-\mathrm{E})=-0.023 \mathrm{PaCO}_{2}-1.35(r=0.89, p<0.001)$. No significant differences in responses of cerebral hemodynamics to hypocarbia were found in comparison of data from this study with previous work in nonasphyxiated lambs. Thus, the response of the cerebral circulation to hypocarbia is not affected by a prior asphyxial insult ir. the newborn lamb. (Pediatr Res 32: 537-541, 1992)
\end{abstract}

\section{Abbreviations}

CBF, cerebral blood flow

$\mathrm{CMRO}_{2}$, cerebral oxygen consumption

$\mathrm{OD}$, cerebral oxygen delivery

$\mathrm{E}$, cerebral fractional oxygen extraction

$\mathrm{PaCO}_{2}$, arterial carbon dioxide tension

$\mathrm{PaO}_{2}$, arterial oxygen tension

Prolonged respiratory alkalosis is frequently used in the treatment of infants with persistent pulmonary hypertension (1). Because decreasing $\mathrm{PaCO}_{2}$ results in cerebral vasoconstriction in

Received January 23, 1992; accepted June 18, 1992.

Correspondence: Adam A. Rosenberg, M.D., The Children's Hospital, Box B070, 1056 East 19th Ave., Denver, CO 80218.

Supported by National Institutes of Health Grant RO1-HL36301. newborn animals (2-5), concerns have existed about the safety of prolonged hyperventilation in these infants $(6,7)$. Previous data from my laboratory (5) as well as that from Hansen et al. (8) have shown that, despite the decrease in CBF with hypocarbia, $\mathrm{CMRO}_{2}$ is maintained at constant levels by an increase in $\mathrm{E}$ as $\mathrm{CBF}$ decreases. The studies described above were performed in nonstressed newborn lambs (5) and piglets (8).

Many infants with persistent pulmonary hypertension of the newborn have previously suffered an asphyxial insult. In previous studies, I have demonstrated abnormalities in autoregulation and in the response to hypoxic hypoxia of the cerebral circulation after an asphyxial insult in the newborn lamb (9). During hypoxia, the increase in $\mathrm{CBF}$ was less than that seen in control animals; with changes in blood pressure, CBF decreased as blood pressure decreased, which is indicative of impaired cerebral autoregulation. In both cases, however, E increased appropriately in response to diminished OD.

The present investigation was designed to address two issues. The primary goal was to examine the vasoconstrictive response postasphyxia to a decrease in $\mathrm{PaCO}_{2}$. The second issue addressed the hypothesis that, if $\mathrm{CBF}$ and OD did fall postasphyxia in response to hypocarbia, $\mathrm{CMRO}_{2}$ would be preserved by an intact increase in $\mathrm{E}$.

\section{MATERIALS AND METHODS}

Ten 1- to 3-d-old newborn lambs were operated on under pentobarbital anesthesia. In each lamb, polyvinyl chloride catheters $(0.034$ inches inner diameter $\times 0.054$ inches outer diameter; Martech Medical Products, Lansdale, PA) were placed in the left ventricle via a femoral artery, in the brachiocephalic artery via an axillary artery, in the abdominal aorta via a femoral artery, in the inferior vena cava via a femoral vein, and in the posterior sagittal sinus proximal to the confluence of the veins via a 1inch diameter burr hole in the middle proximal to the lambdoid sutures. The catheters entering the lamb's extremities were protected in a pouch on the abdomen; the sagittal sinus catheter was cut, pinned, and sutured to the lamb's scalp. The lambs were returned to their mothers and allowed $24 \mathrm{~h}$ to recover. At the time of study, all lambs were standing and feeding normally. Previous work has demonstrated that this recovery period is adequate to eliminate any pentobarbital effect on CBF (10).

Whole and regional brain blood flows were measured using the reference organ radiolabeled microsphere technique as previously described (10). The reference organ was withdrawn through the brachiocephalic artery catheter into a counting vial by a precalibrated pump $(2.40 \mathrm{~mL} / \mathrm{min}$; Harvard Apparatus, Dover, MA). This withdrawal rate is sufficient to prevent errors in the calculation of brain blood flows due to hematocrit differences (11). After completion of the study, the lambs were killed with T-61 Euthanasia Solution (American Hoechst, Sommerville, NJ), position of the catheters was checked, and the brains were removed. The brain was divided into brainstem, cerebellum, midbrain-diencephalon, left and right frontal lobes, left and 
right temporal lobes, left and right occipital lobes, and left and right parietal lobes. The radioactivity in each sample was determined using a three-channel gamma counter (Tracor Analytic, Des Plaines, IL), and regional blood flows were calculated as previously described (12). Whole-brain blood flow was calculated using the sums of the radioactive counts and regional brain weights for all regions rostral to the pons. Adequate central mixing of microspheres using the left ventricular injection site has previously been confirmed in newborn lambs (11). All reference blood samples and all tissue samples contained $>400$ microspheres (13).

Blood samples for $\mathrm{pH}, \mathrm{PaCO}_{2}, \mathrm{PO}_{2}$, and oxygen content were withdrawn anaerobically into heparinized Natelson glass pipettes from the brachiocephalic artery and sagittal sinus catheters. $\mathrm{PO}_{2}$, $\mathrm{PaCO}_{2}$, and $\mathrm{pH}$ were measured at $39.5^{\circ} \mathrm{C}$ using a Radiometer BMS3 Mk2 blood gas analyzer (Radiometer, Copenhagen, Denmark). Hb concentration and oxygen saturation were measured colorimetrically in duplicate by a hemoximeter (Radiometer), and oxygen content was calculated as the product of $\mathrm{Hb}$ and oxygen saturation. Blood pressure and heart rate were continuously monitored in the abdominal aorta (Gould Instruments, Oxnard, CA). Blood pressure was referenced to the right atrium.

On the day of study, the lambs were paralyzed with $0.1 \mathrm{mg} /$ $\mathrm{kg}$ pancuronium, anesthetized with $20 \mu \mathrm{g} / \mathrm{kg}$ initial dose of fentanyl followed by an infusion of $10 \mu \mathrm{g} / \mathrm{kg} / \mathrm{h}$, intubated, and ventilated with an infant ventilator (Bird Co., Palm Springs, CA) with a baseline gas mixture of $30-35 \% \mathrm{O}_{2}$ and $65-70 \% \mathrm{~N}_{2}$ to provide $\mathrm{PaO}_{2}$ of $10.7-16.0 \mathrm{kPa}(80-120 \mathrm{~mm} \mathrm{Hg})$ and a baseline ventilator rate of $25-35$ breaths/min to provide $\mathrm{PaCO}_{2}$ of $4.7-$ $5.3 \mathrm{kPa}(35-40 \mathrm{~mm} \mathrm{Hg})$. Pancuronium and fentanyl have been shown at the doses used in this study to have no effect on CBF and $\mathrm{CMRO}_{2}(9,14)$. Animal body temperature was maintained with a heating pad placed below the chest and abdomen.

The lambs were then subjected to a gradual asphyxial insult by altering inspired gas concentrations and ventilator rate as previously described (12). In a stepwise fashion over $30 \mathrm{~min}$, $\mathrm{PaO}_{2}$ was lowered to $2-2.9 \mathrm{kPa}(15-22 \mathrm{~mm} \mathrm{Hg})$, arterial oxygen content was lowered to $0.66-1.11 \mathrm{mM}$, and $\mathrm{PaCO}_{2}$ was increased to $8-9.3 \mathrm{kPa}(60-70 \mathrm{~mm} \mathrm{Hg})$. Approximately $1 \mathrm{~h}$ into the asphyxia, heart rate and mean arterial blood pressure began a gradual decline over $15-30$ min to a heart rate of 30-60 beats/ min and a blood pressure of $3.3-4.7 \mathrm{kPa}(25-35 \mathrm{~mm} \mathrm{Hg})$. Final heart rate values were $12-25 \%$ of the control heart rate of 250 beats/min, and mean arterial blood pressure dropped to $30-40 \%$ of the control blood pressure of $10.7 \mathrm{kPa}(80 \mathrm{~mm} \mathrm{Hg})$. The lambs were then returned to baseline ventilator settings and inspired oxygen concentration. The initial measurements of brain blood flows, arterial and venous blood gases, and $\mathrm{O}_{2}$ content were made $2 \mathrm{~h}$ after the end of the asphyxial insult. $\mathrm{PaCO}_{2}$ was then altered by adjusting the ventilator rate; $\mathrm{PaO}_{2}$ was maintained with small adjustments in fraction of inspired oxygen. Each lamb was allowed to stabilize for 30 min at each $\mathrm{PaCO}_{2}$ level. After measurements were made at each $\mathrm{PaCO}_{2}$, the lamb was returned to control ventilator settings for $30 \mathrm{~min}$. The order of treatments (low versus higher $\mathrm{PaCO}_{2}$ ) was varied among lambs. Three to four determinations were made in each lamb with $\mathrm{PaCO}_{2}$ varying from $2.3-6.9 \mathrm{kPa}(17-52 \mathrm{~mm} \mathrm{Hg})$. At the completion of the study, the lambs were killed and their brains were removed.

The responses of whole and regional brain blood flows, OD, and $\mathrm{E}$ to changes in $\mathrm{PaCO}_{2}$ were evaluated using least squares linear regression analysis after natural $\log$ transformation. For regional flows, left and right samples were combined because they did not differ. After determination of the standard error of the slope, significance of the slope compared with $b=0$ was assessed at $p<0.05$ using $t$ tests. Regional flow slopes were compared with each other using two-tailed $t$ tests and a $p<0.05$ level of significance. The response of $\mathrm{CMRO}_{2}$ to changes in $\mathrm{PaCO}_{2}$ was evaluated without transformation. Finally, the responses of whole brain flow, regional flows, and extraction to changes in $\mathrm{PaCO}_{2}$ in the present investigation were compared with data from a prior investigation that used nonasphyxiated lambs (5) using two tailed $t$ tests. The nonasphyxiated lamb studies were performed in 101 - to 7 -d-old lambs using an identical surgical approach, $24-\mathrm{h}$ recovery period, and study anesthesia as in the present investigation. The experimental protocol used the same design as the present study except for the absence of the asphyxial insult and 2-h recovery period after asphyxia. The total study time in the nonasphyxiated lambs was $3 \mathrm{~h}$ shorter than that in the present investigation. $\mathrm{PaCO}_{2}$ ranged from 1.6 to $6.1 \mathrm{kPa}(12-46 \mathrm{~mm} \mathrm{Hg})$ with three to four different determinations made in each animal after a 30 -min equilibration period at each level of $\mathrm{PaCO}_{2}$. Other physiologic parameters in the present investigation $\left(\mathrm{PaO}_{2}\right.$, arterial $\mathrm{O}_{2}$ content, blood pressure, heart rate, hematocrit) were compared during normocarbia (4-5.3 $\mathrm{kPa} ; 30-40 \mathrm{~mm} \mathrm{Hg})$, mild hypercarbia $(>5.3 \mathrm{kPa})$, and hypocarbia $(<4 \mathrm{kPa})$ using one way analysis of variance. If the overall $F$ test was significant, individual conditions were compared using paired $t$ tests with a Bonferroni correction for multiple comparisons.

\section{RESULTS}

The response of $\mathrm{CBF}$ to changes in $\mathrm{PaCO}_{2}$ over the range 2.3$6.9 \mathrm{kPa}(17-52 \mathrm{~mm} \mathrm{Hg})$ is depicted in Figure 1. The relationship is nonlinear and is described by the equation $\ln \mathrm{CBF}=0.031$ $\mathrm{PaCO}_{2}+3.15(r=0.83, p<0.001)$. The responses of regional flows were quite similar. For all brain regions examined, the slopes ranged between 0.025 and $0.033 \ln (\mathrm{mL} / 100 \mathrm{~g} / \mathrm{min} / \mathrm{mm}$ $\mathrm{Hg}$ ), with $r$ between 0.72 and 0.85 , all significant at $p<0.001$ (Table 1). The response of OD to changes in $\mathrm{PaCO}_{2}$ is depicted in Figure 2 and is described by the equation $\ln \mathrm{OD}=0.031$ $\mathrm{PaCO}_{2}+1.36(r=0.78, p<0.001)$. The relationship between $\mathrm{E}$ and $\mathrm{PaCO}_{2}$ is depicted in Figure 3 and is described by the equation $\ln (1-\mathrm{E})=-0.023 \mathrm{PaCO}_{2}-1.35(r=0.89, p<0.001) . \mathrm{CMRO}_{2}$

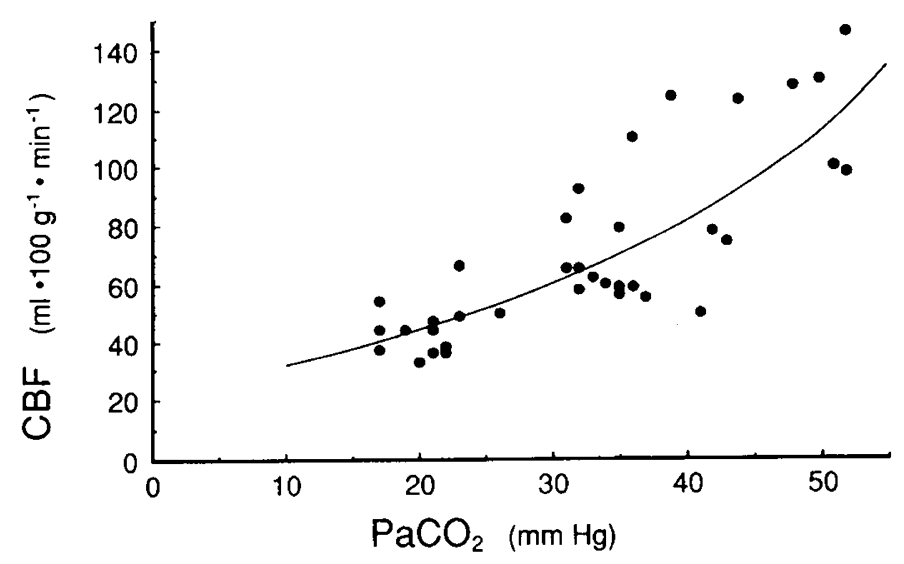

Fig. 1. Scatter plot of CBF vs $\mathrm{PaCO}_{2}$ in 10 hyperventilated postasphyxia newborn lambs. SI unit conversion: $1 \mathrm{~mm} \mathrm{Hg}=0.1333 \mathrm{kPa}$.

Table 1. Regression equations for $\mathrm{PaCO}_{2}$ vs whole brain and regional blood flows for 10 hyperventilated newborn lambs*

\begin{tabular}{lc}
\hline \multicolumn{1}{c}{ Equation } & $r$ \\
\hline $\ln \left(\right.$ Whole brain) $=0.031 \mathrm{PaCO}_{2}+3.15$ & 0.83 \\
$\ln ($ Brainstem $)=0.033 \mathrm{PaCO}_{2}+3.06$ & 0.85 \\
$\ln ($ Cerebellum $)=0.031 \mathrm{PaCO}_{2}+3.21$ & 0.80 \\
$\ln$ (Midbrain $/$ diencephalon $)=0.030 \mathrm{PaCO}_{2}+3.12$ & 0.82 \\
$\ln$ (Frontal cortex) $=0.028 \mathrm{PaCO}_{2}+2.90$ & 0.82 \\
$\ln$ (Temporal cortex) $=0.030 \mathrm{PaCO}_{2}+2.92$ & 0.78 \\
$\ln$ (Occipital cortex) $=0.028 \mathrm{PaCO}_{2}+3.41$ & 0.72 \\
$\ln$ (Parietal cortex) $=0.029 \mathrm{PacO}_{2}+3.31$ & 0.80 \\
$\ln$ (Caudate nuclei) $=0.033 \mathrm{PaCO}_{2}+3.40$ & 0.81 \\
$\ln \left(\right.$ Hippocampi) $=0.025 \mathrm{PaCO}_{2}+2.96$ & 0.71 \\
\hline
\end{tabular}

${ }^{*} n=36, p<0.001$ for all equations. 


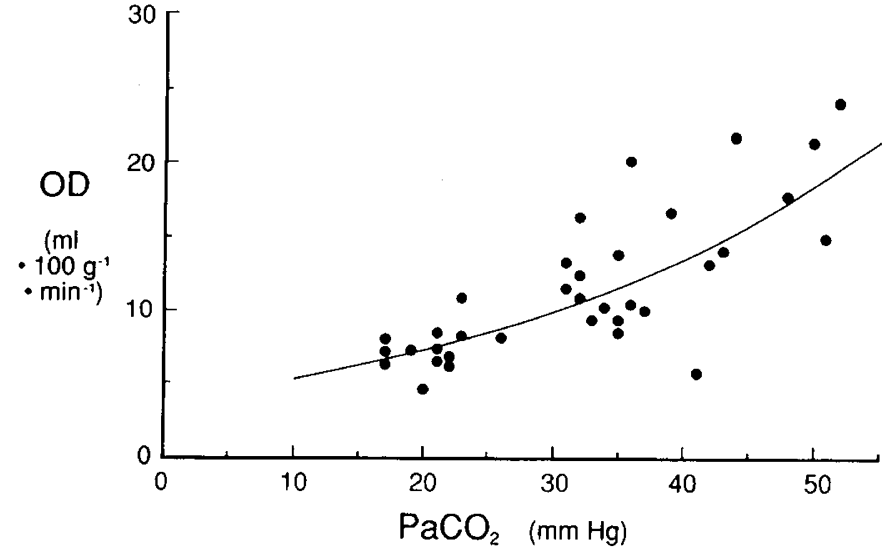

Fig. 2. Scatter plot of $\mathrm{OD}$ vs $\mathrm{PaCO}_{2}$ in 10 hyperventilated postasphyxia newborn lambs. SI unit conversion: $1 \mathrm{~mm} \mathrm{Hg}=0.1333 \mathrm{kPa}$.

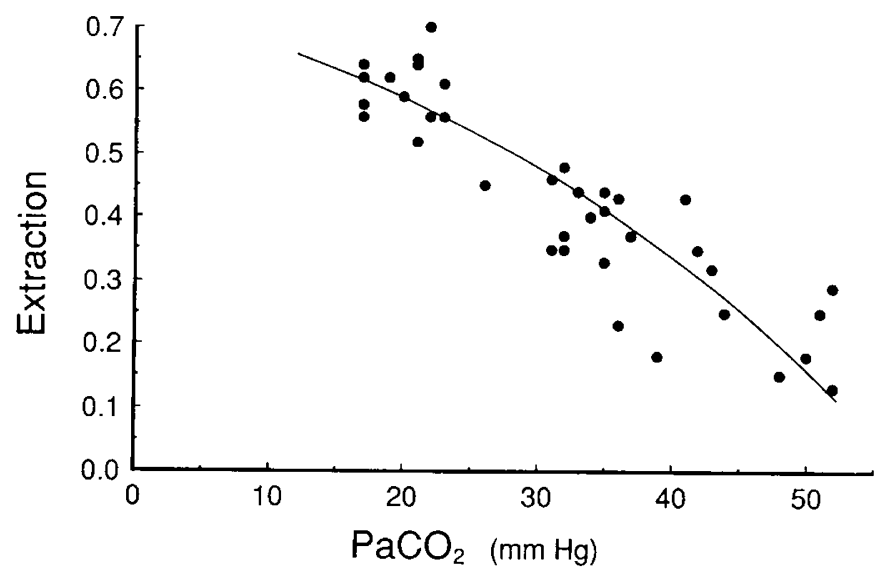

Fig. 3. Scatter plot of $\mathrm{E} v s \mathrm{PaCO}_{2}$ in 10 hyperventilated postasphyxia newborn lambs. SI unit conversion: $1 \mathrm{~mm} \mathrm{Hg}=0.1333 \mathrm{kPa}$.

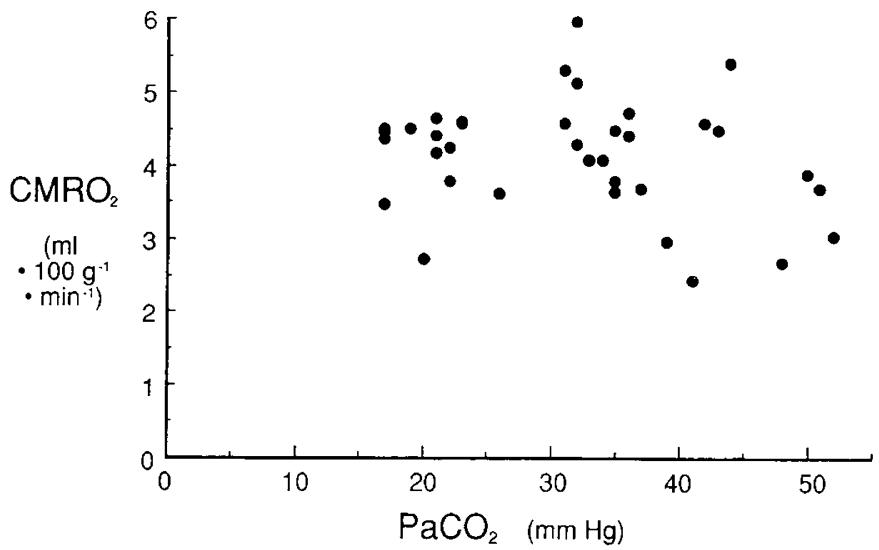

Fig. 4. Scatter plot of cerebral metabolic rate for oxygen $\left(\mathrm{CMRO}_{2}\right)$ vs $\mathrm{PaCO}_{2}$ in 10 hyperventilated newborn lambs. SI unit conversion: 1 $\mathrm{mm} \mathrm{Hg}=0.1333 \mathrm{kPa}$.

did not change with $\mathrm{PaCO}_{2}\left(\mathrm{CMRO}_{2}=-0.021 \mathrm{PaCO}_{2}+4.88 ; r\right.$ $=-0.25, p>0.05$ ) (Fig. 4). During the postasphyxia study period, no significant differences in $\mathrm{PaO}_{2}$, arterial oxygen content, blood pressure, heart rate, or hematocrit were present at different levels of $\mathrm{PaCO}_{2}$ (Table 2).

Table 3 presents a comparison of the responses of $\mathrm{CBF}, \mathrm{OD}$, $\mathrm{CMRO}_{2}$, and $\mathrm{E}$ to changes in $\mathrm{PaCO}_{2}$ postasphyxia and in nonasphyxiated lambs (5). No significant differences in responses were present between groups for any of the cerebral hemodynamic variables. In addition, no significant differences existed in regional flow responses to $\mathrm{PaCO}_{2}$ between nonasphyxiated and asphyxiated lambs.
DISCUSSION

The data from this investigation demonstrate that the responses of the cerebral circulation to hypocarbia are not affected by a prior asphyxial insult. As in the nonasphyxiated lamb, the decreases in whole brain and regional blood flows to decreasing $\mathrm{PaCO}_{2}$ were nonlinear, with no significant differences noted among regions. In addition, $\mathrm{CMRO}_{2}$ was unchanged even during severe hypocarbia due to a compensatory increase in $\mathrm{E}$ and an attenuation of cerebral vasoconstriction at very low levels of $\mathrm{PaCO}_{2}$.

This study is the first to examine responses to hypocarbia after an asphyxial insult in a neonatal model. Some comparison data is available from adult global ischemia models. Although the type of insult is different, these data do provide a framework against which the data from the present investigation can be considered. Nemoto et al. (15), using a model of $15 \mathrm{~min}$ of global ischemia in dogs, showed no change in CBF from normocarbia as $\mathrm{PaCO}_{2}$ was lowered to $2.7 \mathrm{kPa}(20 \mathrm{~mm} \mathrm{Hg})$ during the period of postischemic recirculation. Koch et al. (16) also in dogs, showed a similar response after 12 minutes of ischemia. In contrast, Miller et al. (17), using 5 min of global ischemia in dogs, did show a decrease in CBF with hypocarbia. The insult in the later study is most comparable to the present investigation in which blood pressure below the limits of autoregulation in the lamb (mean arterial pressure $<5.3 \mathrm{kPa} ; 40 \mathrm{~mm} \mathrm{Hg}$ ) and bradycardia (heart rate $<100$ beats $/ \mathrm{min}$ ) are present during the final 5-10 min of the insult. These data would support a conclusion that the response to hypocarbia postasphyxia/ischemia remains intact with less severe insults. In addition, data in newborn piglets subjected to complete ischemia have demonstrated depressed pial arteriolar and CBF responses to hypo- and hypercarbia (1820). These data also support the above conclusion that the findings of an intact response to decreases in $\mathrm{PaCO}_{2}$ in the present investigation are related to the severity of the insult and, in addition, are not related to maturity of the brain.

Previously studied nonasphyxiated controls were used to compare the response of the cerebral circulation to changes in $\mathrm{PaCO}_{2}$ with that in the present postasphyxia lambs. The experimental protocols in the two studies were similar except for the asphyxial insult and 2 -h recovery period in the present investigation. The 3 -h increase in the time of the present investigation and the associated longer exposure to pancuronium and fentanyl compared to "controls" are unlikely to have influenced the results. Previous work from my laboratory has demonstrated the stability of $\mathrm{CBF}$ and $\mathrm{CMRO}_{2}$ in the pancuronium- and fentanyl-anesthetized lamb over an 8 -h period (unpublished results). There is also a small difference in the range of $\mathrm{PaCO}_{2}$ in each study that must be addressed to completely interpret the data (1.6-6.1 $\mathrm{kPa}, 12-$ $46 \mathrm{~mm} \mathrm{Hg}$ in controls; $2.3-6.9 \mathrm{kPa}, 17-52 \mathrm{~mm} \mathrm{Hg}$ in the present study). In addition, there was an overall skew in the data to higher levels of $\mathrm{PaCO}_{2}$ in the present study. However, the response of the cerebral circulation to changes in $\mathrm{PaCO}_{2}$ was identical in both studies, making it unlikely that these small differences in range and distribution of data points were important.

The ability to increase $\mathrm{E}$ in response to a decrease in $\mathrm{OD}$ is consistent throughout all of our studies on postasphyxia cerebral hemodynamics ( 9 , present investigation). This capability has a ready explanation in previous work that examined postasphyxia mitochondria function in newborn lambs (21). These data demonstrated a restoration of previously impaired mitochondria function by $2 \mathrm{~h}$ postasphyxia. This would support a concept that oxygen present can be used and necessary amounts extracted to preserve $\mathrm{CMRO}_{2}$ in the face of diminished oxygen delivery.

Regional blood flow responses were the same in all regions and did not differ from control regional blood flow responses to hypocarbia. Hansen et al. (3) demonstrated a greater percentage of decrease in $\mathrm{CBF}$ compared with cerebellar, thalamic, or brainstem regional blood flows as $\mathrm{PaCO}_{2}$ decreased from $4.7-2.0 \mathrm{kPa}$ $(35-15 \mathrm{~mm} \mathrm{Hg})$ in piglets. Shapiro et al. (22), in newborn 
Table 2. Physiologic parameters with changes in $\mathrm{PaCO}_{2}$ in 10 newborn lambs*

\begin{tabular}{|c|c|c|c|c|c|c|c|}
\hline Condition & $n$ & $\begin{array}{l}\mathrm{PaO}_{2} \\
(\mathrm{kPa}) \\
\end{array}$ & $\begin{array}{l}\mathrm{PaCO}_{2} \\
(\mathrm{kPa})\end{array}$ & $\begin{array}{l}\mathrm{CaO}_{2} \\
(\mathrm{mM})\end{array}$ & $\begin{array}{l}\text { MABP } \\
(\mathrm{kPa})\end{array}$ & $\begin{array}{c}\text { HR } \\
\text { (beats/min) }\end{array}$ & HCT \\
\hline Hybocarbia $\left(\mathrm{PaCO}_{2}<4 \mathrm{kPa}\right)$ & 14 & $15.2 \pm 0.7$ & $2.7 \pm 0.1$ & $7.4 \pm 0.2$ & $9.5 \pm 0.5$ & $250 \pm 11$ & $35 \pm 1$ \\
\hline Normocarbia $\left(\mathrm{PaCO}_{2} 4-5.3 \mathrm{kPa}\right)$ & 13 & $15.3 \pm 0.5$ & $4.5 \pm 0.1 \dagger$ & $7.5 \pm 0.2$ & $10 \pm 0.3$ & $242 \pm 13$ & $36 \pm 1$ \\
\hline Mild hypercarbia $\left(\mathrm{PaCO}_{2}>5.3 \mathrm{kPa}\right)$ & 9 & $14.9 \pm 0.8$ & $6.3 \pm 0.2 \dagger t$ & $6.9 \pm 0.4$ & $10.1 \pm 0.5$ & $222 \pm 16$ & $33 \pm 2$ \\
\hline
\end{tabular}

$*$ Values are mean $\pm \mathrm{SEM} .1 \mathrm{kPa}=7.5 \mathrm{~mm} \mathrm{Hg}$. $\mathrm{CaO}_{2}$, arterial oxygen content; MABP, mean arterial blood pressure; HR, heart rate; HCT, hematocrit.

$\dagger p<0.001$ compared to hypocarbia.

$\ddagger p<0.001$ compared to normocarbia.

Table 3. Regression equations for PaCO2 vs cerebral hemodynamic variables for asphyxiated and nonasphyxiated lambs*

\begin{tabular}{ll}
\hline \multicolumn{1}{c}{ Asphyxia } & \multicolumn{1}{c}{ No asphyxia $\dagger$} \\
\hline $\ln (\mathrm{CBF})=0.031 \mathrm{PaCO}_{2}+3.15$ & $\ln (\mathrm{CBF})=0.025 \mathrm{PaCO}_{2}+3.38$ \\
$\ln (\mathrm{OD})=0.031 \mathrm{PaCO}_{2}+1.36$ & $\ln (\mathrm{OD})=0.026 \mathrm{PaCO}_{2}+1.50$ \\
$\ln (1-\mathrm{E})=-0.023 \mathrm{PaCO}_{2}-1.35$ & $\ln (1-\mathrm{E})=-0.023 \mathrm{PaCO}_{2}-1.37$ \\
$\mathrm{CMRO}_{2}=-0.021 \mathrm{PaCO}_{2}+4.88$ & $\mathrm{CMRO}_{2}=0.0065 \mathrm{PaCO}_{2}+4.39$ \\
\hline
\end{tabular}

* No significant difference in slopes between groups. 5.

† No asphyxia animals are data from historical controls from reference

puppies, showed significant decreases only in subcortical white matter with decreases in $\mathrm{PaCO}_{2}$; multiple gray matter regions showed no decreases in blood flow. Young and Yagel (23), also in newborn puppies, demonstrated regional differences in blood flow responses with hypocarbia. There are several possible explanations for the differences in the data from my newborn lamb studies (present, 5) and the above cited investigations in piglets and puppies. Methodologic differences in study design, blood flow measurement techniques, anesthesia, and difficulty in demonstrating significance when absolute changes are small and experimental variability is high constitute one series of explanations. In addition, species differences offer another explanation because the newborn lamb has a more mature brain at birth than either puppies or piglets. However, it is more likely that the discrepancies relate to methodology rather than species-specific maturational differences. This is supported by the work of Reuter and Disney (4) in puppies demonstrating regional blood flow responses similar to those seen in newborn lambs. Regional blood flow decreased in a nonlinear fashion and to a similar degree in all regions examined (4). This last study is most similar to the newborn lamb studies in design and method of blood flow measurement.

Despite the availability of several studies, disagreement still exists about whether reduction of CBF with hypocarbia is harmful. Work in adult animals and humans has shown decreases in cerebral tissue $\mathrm{PO}_{2}$, the development of abnormalities in electroencephalographic recordings, and decreased $\mathrm{CMRO}_{2}$ during hyperventilation (24-28). These data were supported by the demonstration by Reuter and Disney (4) of decreased $\mathrm{CMRO}_{2}$ with acute hypocarbia in newborn puppies. In contrast, both Hansen et al. (8) and my laboratory (5) have provided data supporting the safety of hypocarbia. Hansen et al. (8) studied changes in $\mathrm{CMRO}_{2}$ in newborn piglets during both acute and more prolonged $(2 \mathrm{~h})$ hypocarbia. After $30 \mathrm{~min}$ of hypocarbia, both $\mathrm{CBF}$ and $\mathrm{CMRO}_{2}$ were significantly decreased; however, by $60 \mathrm{~min}$ $\mathrm{CMRO}_{2}$ had returned to baseline. Our prior work showed stable $\mathrm{CMRO}_{2}$ in the newborn lamb with $\mathrm{PaCO}_{2}$ lower than $2.7 \mathrm{kPa}(20$ $\mathrm{mm} \mathrm{Hg}$ ) (5). Furthermore, work in both newborns and adults has demonstrated normal levels of high-energy phosphates with $\mathrm{PaCO}_{2}$ as low as $1.6 \mathrm{kPa}(12 \mathrm{~mm} \mathrm{Hg})(23,29,30)$. All of these studies were done in nonasphyxiated animals. However, the infants on which therapeutic hyperventilation is often applied (those with persistent pulmonary hypertension) (1) have frequently suffered a prior asphyxial insult. Thus, these data evaluating the response to hypocarbia postasphyxia are germane to that issue. To the extent that a stable $\mathrm{CMRO}_{2}$ is indicative of a successful adaptation to hypocarbia, these data are reassuring regarding the use of respiratory alkalosis in the treatment of pulmonary hypertension. It is important to note, though, that the use of radiolabeled microspheres precluded an assessment of histologic injury in this model. Therefore, conclusions about the safety of therapeutic respiratory alkalosis must be considered in this regard. However, these data are consistent with outcome data in neonates who have been hyperventilated for treatment of persistent pulmonary hypertension $(6,7)$. Despite representing an extremely high-risk group for CNS damage, their outcome is generally favorable.

Acknowledgments. The author thanks I-da Fan, Yu Ching Fan Cheng, and Stacia Hall for technical support and Nancy Briggs for preparation of this manuscript.

\section{REFERENCES}

1. Peckham GH, Fox WW 1978 Physiologic factors affecting pulmonary artery pressure in infants with persistent pulmonary hypertension. $J$ Pediatr 93:1005-1010

2. Cartwright D, Gregory GA, Lou H, Heymann MA 1984 The effect of hypocarbia on the cardiovascular system of puppies. Pediatr Res 18:685-690

3. Hansen NB, Brubakk AM, Bratlid D, Oh W, Stonestreet BS 1984 The effects of variations in $\mathrm{PaCO}_{2}$ on brain blood flow and cardiac output in the newborn piglet. Pediatr Res 18:1132-1136

4. Reuter JH, Disney TA 1986 Regional cerebral blood flow and cerebral metabolic rate of oxygen during hyperventilation in the newborn dog. Pediatr Res 20:1102-1106

5. Rosenberg AA 1988 Response of the cerebral circulation to profound hypocarbia in neonatal lambs. Stroke 19:1365-1370

6. Ferrara B, Johnson DE, Chang P-N, Thompson TR 1984 Efficacy and neurologic outcome of profound hypocapneic alkalosis for the treatment of persistent pulmonary hypertension in infancy. J Pediatr 105:457-461

7. Ballard RA, Leonard $\mathrm{CH} 1984$ Developmental follow-up of infants with persistent pulmonary hypertension of the newborn. Clin Perinatol 11:737744

8. Hansen NB, Nowicki PT, Miller RR, Malone T, Bickers RG, Menke JA 1986 Alterations in cerebral blood flow and oxygen consumption during prolonged hypocarbia. Pediatr Res 20:147-150

9. Rosenberg AA 1988 Regulation of cerebral blood flow after asphyxia in neonatal lambs. Stroke 19:239-244

10. Rosenberg AA, Jones MD, Traystman RJ, Simmons MA, Molteni RA 1982 Response of cerebral blood flow to changes in $\mathrm{PCO}_{2}$ in fetal, newborn, and adult sheep. Am J Physiol 242:H862-H866

11. Rosenberg AA, Jones MD, Koehler RC, Traystman RJ, Lister G 1983 Precautions for measuring blood flow during anemia with the microsphere tech nique. Am J Physiol 244:H308-H311

12. Rosenberg AA 1986 Cerebral blood flow and $\mathrm{O}_{2}$ metabolism after asphyxia in neonatal lambs. Pediatr Res 20:778-782

13. Buckberg GD, Luck JL, Payne B, Hoffman JIE, Archie J, Fixler DE 1971 Some sources of error in measuring regional blood flow with radioactive microspheres. J Appl Physiol 31:598-604

14. Belik J, Wagerle LE, Delivoria-Papadopoulos M 1984 Cerebral blood flow and metabolism following pancuronium bromide in newborn lambs. Pediatr Res 18:1305-1308

15. Nemoto EM, Snyder JV, Carroll RG, Morita H 1975 Global ischemia in dogs: cerebrovascular $\mathrm{CO}_{2}$ reactivity and autoregulation. Stroke 6:425-431

16. Koch KA, Jackson DL, Schmiedl M, Rosenblatt JI 1984 Total cerebral ischemia: effect of alterations in arterial $\mathrm{PCO}_{2}$ on cerebral microcirculation. $\mathrm{J}$ Cereb Blood Flow Metab 4:343-349

17. Miller CL, Alexander K, Lampard DG, Brown WA, Griffiths R 1980 Local cerebral blood flow following transient cerebral ischemia. II. Effect of arterial $\mathrm{PCO}_{2}$ on reperfusion following global ischemia. Stroke 11:542-548

18. Leffler CW, Beasley DG, Busija DW 1989 Cerebral ischemia alters cerebral microvascular reactivity in newborn pigs. Am J Physiol 257:H266-H271

19. Leffler CW, Busija DW, Armstead WM, Mirro R, Beasley DG 1989 Ischemia 
alters cerebral vascular responses to hypercapnia and acetylcholine in piglets. Pediatr Res 25:180 183

20. Helfaer MA, Kirsch JR, Haun SE, Koehler RC, Traystman RJ 1991 Age related cerebrovascular reactivity to $\mathrm{CO}_{2}$ after cerebral ischemia in swine. Am J Physiol 260:H1482-1488

21. Rosenberg AA, Parks JK, Murdaugh E, Parker WD 1989 Mitochondrial function after asphyxia in newborn lambs. Stroke 20:674-679

22. Shapiro HM, Greenberg JH, vanHorn Naughton K, Reivich M 1980 Heterogeneity of local cerebral blood flow: $\mathrm{PaCO}_{2}$ sensitivity in neonatal dogs. $\mathrm{J}$ Appl Physiol 49:113-118

23. Young RSK, Yagel SK 1984 Cerebral physiological and metabolic effects of hyperventilation in the neonatal dog. Ann Neurol 16:337-342

24. Kennealy JA, McLennan JE, Loudon RG, McLaurin RL 1980 Hyperventilation induced cerebral hypoxia. Am Rev Respir Dis 122:407-412
25. Sugioka K, Davis DA 1960 Hyperventilation with oxygen: a possible cause of cerebral hypoxia. Anesthesiology 21:135-143

26. Meyer JF, Gotoh F 1960 Metabolic and electroencephalographic effects of hyperventilation. Arch Neurol 5:539-551

27. Alexander SC, Smith TC, Strobel G, Stephen GW, Wollman H 1968 Cerebral carbohydrate metabolism of man during respiratory and metabolic alkalosis. J Appl Physiol 24:66-72

28. Grote J, Zimmer K, Schubert R 1981 Effects of severe arterial hypocapnia on regional blood flow regulation, tissue $\mathrm{PO}_{2}$, and metabolism in the brain cortex of cats. Pflugers Arch 391:195-199

29. Granholm L, Lukjanova L, Siesjo BK 1969 The effect of marked hyperventilation upon tissue levels of NADH, lactate, pyruvate, phosphocreatine, and adenosine phosphates of rat brain. Acta Physiol Scand 77:179-190

30. Carlsson C, Nilsson L, Siesjo BK 1974 Cerebral metabolic changes in arterial hypocapnia of short duration. Acta Anesthesiol Scand 18:104-113

\section{Announcement}

\section{Call for Abstracts}

The American Pediatric Society and The Society for Pediatric Research announce that the abstract deadline for the 1993 Annual Meeting (May 3-6, 1993, Sheraton Washington Hotel, Washington, DC) has been set as January 5, 1993. For further information contact: APS/SPR Association Headquarters, 141 Northwest Point Blvd., P.O. Box 675, Elk Grove Village, IL 60009-0675. 